\title{
Analisis Kepuasan Mahasiswa Terhadap Pelayanan Laboratorium Jaringan Menggunakan Pendekatan Importance-Performance Analysis
}

\author{
Syukhri \\ Jurusan Teknik Elektronika, Fakultas Teknik, Universitas Negeri Padang \\ *Corresponding author, e-mail: syukhri@ft.unp.ac.id
}

\begin{abstract}
Abstrak-Penelitian ini bertujuan untuk menganalisis kepuasan mahasiswa terhadap pelayanan laboratorium Jaringan Jurusan Teknik Elektronika Fakultas Teknik Universitas Negeri Padang menggunakan pendekatan Importance Performance Analysis (IPA) serta sebagai bahan evaluasi dalam memaksimalkan tujuan pembelajaran, khususnya untuk matakuliah jaringan. Teknik sampling menggunakan simple random sampling, dengan sumber data penelitian meliputi 75 responden mahasiswa program studi Pendidikan Teknik Informatika, Jurusan Teknik Elektronika Fakultas Teknik Universitas Negeri Padang angkatan 2015. Analisis data berupa uji validitas dan reliabilitas menggunakan SPSS versi 17.0. Penelitian ini menghasilkan kualitas layanan yang diterima mahasiswa belum sesuai dengan yang diharapkan. Atribut yang masuk ke dalam kuadran I merupakan atribut yang perlu ditingkatkan dengan prioritas utama. Atribut tersebut adalah kondisi ruang laboratorium yang nyaman, akses internet yang baik, kualitas hardware yang baik, keramahan teknisi laboratorium, kemudahan mahasiswa dalam memperoleh pelayanan, keberadaan tenaga teknisi laboratorium, dan kemudahan teknisi laboratorium untuk dihubungi. Untuk itu diperlukan upaya peningkatan yang signifikan terhadap atribut tersebut. Dengan adanya analisis kepuasan mahasiswa terhadap laboratorium Jaringan Jurusan Teknik Elektronika Fakultas Teknik Universitas Negeri Padang diharapkan dapat dilakukan peningkatan dengan prioritas atribut yang berada di kuadran $I$.
\end{abstract}

Kata kunci: analisis, kepuasan, laboratorium, IPA

Abstract - This study aims to analyze student satisfaction with the Network Laboratory services of the Electronics Engineering Department, Faculty of Engineering, Universitas Negeri Padang using the Importance Performance Analysis (IPA) approach and as an evaluation material in maximizing learning objectives, especially for networking subjects. The sampling technique uses simple random sampling, with research data sources covering 75 respondents students of Informatics Engineering Education program, Department of Electronics Engineering Faculty of Engineering, Universitas Negeri Padang class 2015. Data analysis in the form of validity and reliability tests using SPSS version 17.0. This research resulted in the quality of services received by students not as expected. Attributes that enter into quadrant I are attributes that need to be improved with top priority. These attributes are the conditions of a comfortable laboratory room, good internet access, good hardware quality, laboratory technician friendliness, ease of students in obtaining services, the presence of laboratory technicians, and the ease of laboratory technicians to be contacted. For this reason, a significant increase in these attributes is needed. With the analysis of student satisfaction on the Network Laboratory of the Electronics Engineering Department, Faculty of Engineering, Universitas Negeri Padang, it is expected that improvements can be made with priority attributes in quadrant I.

This is an open access article distributed under the Creative Commons 4.0 Attribution License, which permits unrestricted use, distribution, and reproduction in any medium, provided the original work is properly cited. C2018 by Author and Universitas Negeri Padang

\section{Pendahuluan}

Laboratorium jaringan Jurusan Teknik Elektronika Fakultas Teknik Universitas Negeri Padang (FT UNP) merupakan salah satu fasilitas pendukung dalam meningkatkan proses pembelajaran. Laboratorium jaringan tersebut bertujuan memberikan pengetahuan dan keterampilan dasar dalam bidang jaringan khususnya bagi mahasiswa program studi 
Pendidikan Teknik Informasi Jurusan Teknik Elektronika FT UNP. Untuk memenuhi kebutuhan dan kepuasan mahasiswa salah satu yang dilakukan pihak manajemen adalah melakukan peningkatan secara terus menerus terhadap kualitas pelayanan laboratorium komputer khususnya laboratorium jaringan.

Seiring dengan upaya peningkatan yang dilakukan, masih terdapat permasalahan yang ditemui di lapangan. Permasalahan tersebut diantaranya adalah kapasitas ruang laboratorium yang dirasa belum memadai yang disebabkan banyaknya rak server yang ada di dalam ruangan laboratorium. Selain itu hal yang dirasa penting adalah belum adanya teknisi tetap laborium yang membantu dalam proses pembelajaran dan melakukan maintenance perangkat, dimana saat ini masih dilakukan oleh petugas administrasi jurusan yang tidak mempunyai kompetensi di bidang jaringan. Kendala lain yang dihadapi mahasiswa adalah lambatnya akses internet di laboratorium jaringan sehingga mahasiswa merasa kurang puas terhadap fasilitas yang disediakan.

Sebagai bahan evaluasi dalam memberikan pelayanan yang maksimal sehingga mahasiswa merasa puas dan tujuan pembelajaran tercapai maka diperlukan penelitian mengenai analisis kepuasan mahasiswa terhadap pelayanan laboratorium jaringan pada jurusan Teknik Elektronika FT UNP dengan metode Service Quality (Servqual) dan Importance Performance Analysis (IPA). Dengan menggunakan metode Servqual dapat diketahui nilai gap (nilai kualitas pelayanan) dari setiap atribut kebutuhan, dapat diketahui bagaimana harapan dan bagaimana kepuasan konsumen atas pelayanan yang diberikan, dapat diketahui atribut mana yang harus menjadi focus perbaikan selanjutnya, metode Servqual telah menjadi standar penilaian atas berbagai dimensi kualitas pelayanan, berbagai riset menunjukan bahwa metode servqual valid untuk berbagai konteks layanan, dan kuesioner Servqual adalah reliabel, artinya pertanyaan-pertanyaan dipersepsikan sama oleh responden yang berbeda [1]

Melalui pendekatan IPA dapat menunjukkan atribut produk/jasa yang perlu ditingkatkan ataupun dikurangi untuk menjaga kepuasan mahasiswa. Hasilnya relatif mudah diinterpretasikan, skalanya relatif mudah dimengerti dan membutuhkan biaya yang rendah [2].

\section{StUdi Pustaka}

Kualitas pelayanan merupakan segala sesuatu yang memfokuskan pada usaha-usaha memenuhi kebutuhan dan keinginan para konsumen yang disertai dengan ketepatan dalam menyampaikannya sehingga tercipta kesesuaian yang seimbang dengan harapan konsumen. Aplikasi kualitas sebagai sifat dari penampilan produk atau kinerja merupakan bagian utama strategi perusahaan dalam rangka meraih keunggulan yang berkesinambungan, baik sebagai pemimpin dasar ataupun sebagai strategi untuk terus tumbuh [3].

Konsep dasar kepuasan konsumen adalah tingkat harapan dan pelayanan yang diberikan kepada konsumen. Konsep dasar ServQual adalah (a) Perceived quality vs objective quality Konsumen dan peneliti memiliki pemahaman berbeda tentang kualitas. Peneliti mendefinisikan kualitas secara konseptual. Konseptual artinya adalah membedakan antara kualitas mekanis dan kualitas sumber daya manusia. Kualitas mekanis meliputi aspek objektif suatu proses, sedangkan kualitas sumber daya manusia meliputi bagaimana respon subjektif terhadap suatu proses. (b) Quality as attitude, kualitas dilihat sebagai bentuk evaluasi keseluruhan suatu produk. (c) Quality versus satisfaction, kepuasan adalah suatu titik simpulan psikologis mengenai perasaan konsumen terhadap pengalaman yang diterimanya dan harapan mereka. (d) Expectation compared to perceptions, kualitas pelayanan berakar dari perbandingan antara pelayanan yang seharusnya diberikan kepada konsumen dan persepsi konsumen terhadap performa pelayanan[4]. Terdapat lima (5) dimensi pada model servqual yaitu tangibles, reliability, responsive, assurance, dan emphaty.

Gap atau kesenjangan kualitas layanan merupakan selisih antara persepsi dan harapan. Jika gap positif (persepsi > harapan) maka layanan dikatakan "surprise" dan memuaskan. Jika gap nol (persepsi = harapan) maka layanan dikatakan berkualitas dan memuaskan. Jika gap negative (persepsi < harapan) maka layanan dikatakan tidak berkualitas dan tidak memuaskan. [5]

Importance Performance Analysis (IPA) diperkenalkan oleh Martilla dan James pada tahun 1977 terdokumentasi dengan baik serta telah mampu menunjukkan kemampuan untuk menyediakan solusi manajerial dengan informasi 
yang berharga untuk pengukuran kepuasan dan alokasi sumber daya yang efisien di dalam format yang sesuai, metode ini berujuan untuk mengukur hubungan antara persepsi konsumen dan prioritas peningkatan kualitas produk/jasa yang dikenal pula sebagai quadrant analysis [6]. IPA terdiri dari empat kuadran ditunjukan oleh Gambar 1:

\begin{tabular}{|l|l|}
\hline Kuadran I & Kuadran II \\
$\begin{array}{l}\text { Concentrate Here } \\
\text { High Importance } \\
\text { Low Performance }\end{array}$ & $\begin{array}{l}\text { Keep Up the Good Work } \\
\text { High Importance } \\
\text { High Performance }\end{array}$ \\
\hline Kuadran III & Kuadran IV \\
Low Priority & Possible Overkill \\
Low Importance & Low Importance \\
Low Performance & High Performance \\
\hline
\end{tabular}

Gambar 1. Kuadran IPA

1. Kuadran I (High Importance/Low Performance): biasa disebut concentrate here. Atribut-atribut yang terdapat pada kuadran ini mempresentasikan hal-hal penting namun kualitasnya rendah, sehingga harus ditingkatkan dan merupakan prioritas tertinggi yang perlu dilakukan oleh perusahaan.

2. Kuadran II (High Importance/High Performance): biasa disebut dengan Keep Up The Good Work. Atribut-atribut yang terdapat dalam kuadran ini mempresentasikan hal-hal penting dan kualitasnya tinggi. Atribut-atribut inilah yang menjadi kekuatan, pilar, dan kebanggaan perusahaan.

3. Kuadran III (Low Importance/Low Performance): biasa disebut low priority. Atribut-atribut dalam kuadran ini mempresentasikan hal-hal yang kurang penting dan berkualitas rendah.

4. Kuadran IV (Low Importance/High Performance): biasa disebut possible overkill. Atribut-atribut yang terdapat pada kuadran ini mempresentasikan hal-hal yang kurang penting dan berkualitas tinggi. Manajemen tidak perlu mengambil tindakan lebih lanjut terhadap indikator yang berada pada kuadran ini.

\section{Metode}

Tahapan penelitian diawali dengan survei pendahuluan untuk mengetahui kondisi laboratorium jaringan jurusan Teknik Elektronika FT UNP. Studi literatur dilakukan untuk mencari informasi yang berkaitan dengan materi penelitian. Kemudian dilanjutkan dengan pengumpulan data dengan menyebarkan kuesioner. Sampel pada penelitian ini adalah mahasiswa program studi Pendidikan Teknik Informatika jurusan Teknik Elektronika FT UNP angkatan 2015. Jumlah sampel penelitian sebanyak 75 responden berdasarkan perhitungan dengan metode Slovin [2].

Hasil pengumpulan data di analisis menggunakan metode Importance Performance Analysis (IPA). Dengan menggunakan metode IPA terdapat dua variabel yang mewakili huruf $\mathrm{X}$ dan $\mathrm{Y}$, dimana $\mathrm{X}$ merupakan tingkat kinerja/realita jurusan Teknik Elektronika FT UNP yang dapat memberikan kepuasan bagi mahasiswa, sedangkan $\mathrm{Y}$ merupakan tingkat kepentingan/ekspektasi mahasiswa. Rumus yang digunakan yaitu:

$T k i=\frac{X i}{Y i} \times 100 \%$

Dengan :

Tki $=$ Tingkat Kesesuaian Responden

$\mathrm{Xi}=$ Skor penilaian kinerja/realita

$\mathrm{Yi}=$ Skor penilaian kepentingan/ekspektasi

Untuk setiap faktor yang mempengaruhi kepuasan mahasiswa adalah dengan :

$$
\begin{aligned}
& \bar{X}=\frac{\sum X i}{n} \\
& \bar{Y}=\frac{\sum Y i}{n} \\
& \text { dengan: } \\
& \bar{X} \quad=\text { Skor rata-rata tingkat kinerja } \\
& \bar{Y} \quad=\text { Skor rata-rata tingkat kepentingan } \\
& \mathrm{n} \quad=\text { jumlah responden }
\end{aligned}
$$

Diagram kartesius merupakan suatu bangunan atas empat bagian yang dibatasi oleh dua buah garis berpotongan tegak lurus pada titik-titik $(\overline{\bar{X}}, \overline{\bar{Y}})$. Dimana $\overline{\bar{X}}$ merupakan rata-rata skor tingkat kinerja dari suatu atribut dan $\overline{\bar{Y}}$ adalah rata-rata skor tingkat kepentingan dari atribut yang mempengaruhi kepuasan pelanggan. Rumus yang digunakan adalah:

$\overline{\bar{X}}=\frac{\sum_{i=1}^{k} \overline{X \imath}}{n}$
$\overline{\bar{Y}}=\frac{\sum_{i=1}^{k} \overline{Y \iota}}{n}$

dimana

$\mathrm{K}=$ banyaknya atribut yang mempengaruhi kepuasan konsumen

$\mathrm{n}=$ jumlah pernyataan 


\section{HASIL DAN PEMBAHASAN}

Analisis Uji validitas dihitung dengan menghitung korelasi produk momen (r) pada tiap kriteria pernyataan. Dari uji validitas yang dilakukan, baik penilaian persepsi maupun harapan mahasiswa diperoleh $r_{\text {hitung }}>r_{\text {tabel }}(0.138)$ dapat disimpulkan bahwa semua butir pernyataan tersebut adalah valid.

Analisis Uji Reliabilitas Data dilakukan dengan menggunakan SPSS Statistic 17.0. Dari hasil pengujian tersebut diperoleh Cronbach's Alpha $=0.8$ dikarenakan Cronbach's Alpha $=$ $0.8>0.6$, maka dapat disimpulkan bahwa instrumen penelitian yang digunakan untuk mengukur kepuasan mahasiswa dikatakan reliable.

\section{Analisis Importance Performance Analysis}

Dalam menentukan tingkat kesesuaian responden diperoleh dari hasil perbandingan skor kinerja dengan skor kepentingan. Tingkat kesesuaian responden diperoleh dengan cara membagi skor penilaian kinerja dengan penilaian kepentingan dikali $100 \%$. Dimana $\mathrm{Xi}$ merupakan skor penilaian kinerja dan Yi merupakan skor penilaian kepentingan. Hasil perolehan tingkat kesesuaian responden dapat dilihat pada Tabel 1.

Tabel 1. Tingkat Kesesuaian Responden

\begin{tabular}{|c|c|c|c|c|}
\hline No & Kriteria & $\mathbf{X i}$ & $\mathbf{Y i}$ & Tki \\
\hline \multicolumn{5}{|c|}{ Dimensi Tangibles } \\
\hline 1 & Kebersihan ruang laboratorium & 3.267 & 4.707 & 69.41 \\
\hline 2 & $\begin{array}{l}\text { Kondisi ruang laboratorium } \\
\text { nyaman }\end{array}$ & 3.12 & 4.6 & 67.83 \\
\hline 3 & Akses internet yang baik & 2.267 & 4.84 & 46.83 \\
\hline 4 & $\begin{array}{l}\text { Fasilitas perangkat pembelajaran } \\
\text { lengkap }\end{array}$ & 3.48 & 4.453 & 78.14 \\
\hline 5 & Kualitas hardware yang baik & 3 & 4.653 & 64.47 \\
\hline 6 & Kualitas software yang baik & 3.493 & 4.293 & 81.37 \\
\hline \multicolumn{5}{|c|}{ Dimensi Reliability } \\
\hline 1 & $\begin{array}{l}\text { Penggunaan laboratorium sesuai } \\
\text { dengan bidang keilmuan }\end{array}$ & 3.227 & 4.72 & 68.36 \\
\hline 2 & $\begin{array}{l}\text { Ketersediaan tata tertib } \\
\text { laboratorium }\end{array}$ & 3.627 & 4.293 & 84.47 \\
\hline 3 & $\begin{array}{l}\text { Keberadaan petugas kebersihan } \\
\text { laboratorium }\end{array}$ & 3.08 & 4.533 & 67.94 \\
\hline 4 & $\begin{array}{l}\text { Tingkat keamanan terhadap sarana } \\
\text { dan prasarana laboratorium }\end{array}$ & 3.453 & 4.32 & 79.94 \\
\hline 5 & $\begin{array}{l}\text { Pelaksanaan waktu belajar di } \\
\text { laboratorium sesuai dengan } \\
\text { ketentuan }\end{array}$ & 3.373 & 4.547 & 74.19 \\
\hline
\end{tabular}

\begin{tabular}{|c|c|c|c|c|}
\hline No & Kriteria & $\mathbf{X i}$ & $\mathbf{Y i}$ & Tki \\
\hline 6 & $\begin{array}{l}\text { Ketersediaan modul/handout/bahan } \\
\text { kuliah }\end{array}$ & 3.307 & 4.507 & 73.37 \\
\hline \multicolumn{5}{|c|}{ Dimensi Responsive } \\
\hline 1 & Keramahan teknisi laboratorium & 2.893 & 4.587 & 63.08 \\
\hline 2 & $\begin{array}{l}\text { Tanggungjawab teknisi } \\
\text { laboratorium }\end{array}$ & 3.52 & 4.4 & 80 \\
\hline 3 & $\begin{array}{l}\text { Kemudahan mahasiswa dalam } \\
\text { memperoleh pelayanan }\end{array}$ & 2.973 & 4.733 & 62.82 \\
\hline \multicolumn{5}{|c|}{ Dimensi Assurance } \\
\hline 1 & $\begin{array}{l}\text { Tersedianya tenaga pengajar } \\
\text { profesional dalam mengajar }\end{array}$ & 3.52 & 4.64 & 75.86 \\
\hline 2 & $\begin{array}{l}\text { Keberadaan tenaga teknisi } \\
\text { laboratorium }\end{array}$ & 2.253 & 4.8 & 46.94 \\
\hline 3 & $\begin{array}{l}\text { Pemeliharaan computer (software, } \\
\text { virus) }\end{array}$ & 3.227 & 4.467 & 72.24 \\
\hline \multicolumn{5}{|c|}{ Dimensi Empaty } \\
\hline 1 & $\begin{array}{l}\text { Sikap dan perilaku teknisi } \\
\text { laboratorium sangat baik }\end{array}$ & 2.96 & 4.553 & 65.29 \\
\hline 2 & $\begin{array}{l}\text { Tegur sapa dan tutur kata teknisi } \\
\text { laboratorium dalam berkomunikasi }\end{array}$ & 3.213 & 4.44 & 72.37 \\
\hline 3 & $\begin{array}{l}\text { Kemudahaan teknisi laboratorium } \\
\text { untuk dihubungi }\end{array}$ & 2.987 & 4.547 & 65.69 \\
\hline
\end{tabular}

Rata-rata persepsi tiap atribut merupakan dasar untuk menentukan apakah tiap atribut kinerja sudah baik atau belum yaitu dengan membandingkan terhadap rerata dari rata-rata seluruh atribut $(\mathrm{X})$ diperoleh hasil 3.154. Ratarata harapan tiap atribut merupakan dasar untuk menentukan apakah atribut tersebut penting atau tidak penting yaitu dengan membandingkan terhadap rerata dari rata-rata seluruh atribut $(\mathrm{Y})$ diperoleh hasil 4.553. Nilai rata-rata persepsi dan harapan tersebut digunakan untuk menganalisis data dalam diagram kartesius pada Gambar 2.

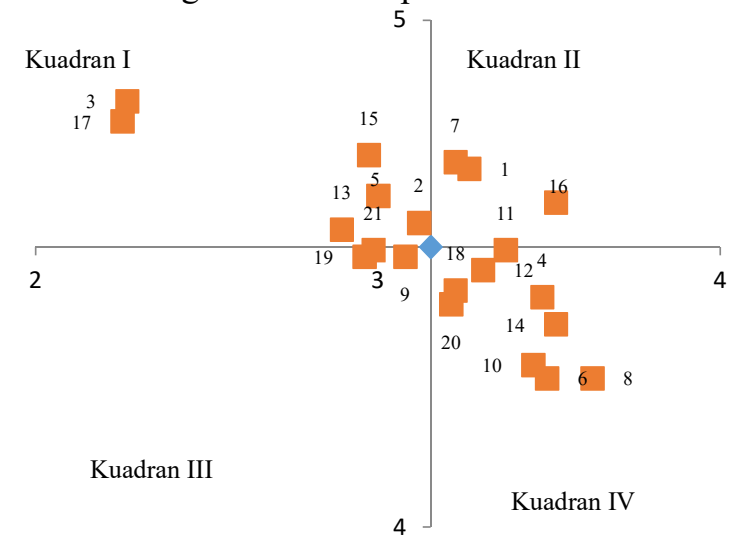

Gambar 2. Kuadran Importance Performance Analysis 
Kuadran I concentrate here; Atribut-atribut yang terdapat pada kuadran ini mempresentasikan hal-hal penting namun kualitasnya rendah, sehingga harus ditingkatkan dan merupakan prioritas tertinggi yang perlu dilakukan oleh perusahaan. Atribut tersebut adalah kondisi ruang laboratorium yang nyaman, Akses internet yang baik, kualitas hardware yang baik, keramahan teknisi laboratorium, Kemudahan mahasiswa dalam memperoleh pelayanan, keberadaan tenaga teknisi laboratorium, kemudahan teknisi laboratorium untuk dihubungi.

Kuadran II keep up the good work; Atributatribut yang terdapat dalam kuadran ini mempresentasikan hal-hal penting dan kualitasnya tinggi. Atribut-atribut inilah yang menjadi kekuatan, pilar, dan kebanggaan perusahaan. Atribut tersebut adalah kebersihan ruang laboratorium, penggunaan laboratorium sesuai dengan bidang keilmuan, tersedianya tenaga pengajar profesional dalam mengajar.

Kuadran III low priority; Atribut-atribut dalam kuadran ini mempresentasikan hal-hal yang kurang penting dan berkualitas rendah. Atribut tersebut adalah keberadaan petugas kebersihan laboratorium, sikap dan perilaku teknisi laboratorium sangat baik.

Kuadran IV possible overkill; Atribut-atribut yang terdapat pada kuadran ini mempresentasikan hal-hal yang kurang penting dan berkualitas tinggi. Manajemen tidak perlu mengambil tindakan lebih lanjut terhadap indikator yang berada pada kuadran ini. Atribut tersebut adalah Fasilitas perangkat pembelajaran lengkap, Kualitas software yang baik, Ketersediaan tata tertib laboratorium, Tingkat keamanan terhadap sarana dan prasarana laboratorium, Ketersediaan modul/handout/bahan kuliah, Tanggungjawab teknisi laboratorium, Pemeliharaan computer (software, virus), Tegur sapa dan tutur kata teknisi laboratorium dalam berkomunikasi.

\section{KESIMPULAN}

Berdasarkan hasil analisis dan pembahasan yang telah dilakukan, maka dapat diambil kesimpulan bahwa kualitas layanan yang diterima mahasiswa belum sesuai dengan yang diharapkan. Atribut yang masuk ke dalam kuadran I merupakan atribut yang perlu ditingkatkan dengan prioritas utama. Atribut tersebut adalah kondisi ruang laboratorium yang nyaman, akses internet yang baik, kualitas hardware yang baik, keramahan teknisi laboratorium, kemudahan mahasiswa dalam memperoleh pelayanan, keberadaan tenaga teknisi laboratorium, kemudahan teknisi laboratorium untuk dihubungi. Untuk itu diperlukan upaya peningkatan yang signifikan terhadap atribut tersebut. Atribut yang penting dan mempunyai kualitas yang tinggi dan merupakan kebanggaan laboratorium jaringan jurusan Teknik Elektronika FT UNP adalah kebersihan ruang laboratorium, penggunaan laboratorium sesuai dengan bidang keilmuan, tersedianya tenaga pengajar profesional dalam mengajar. Dengan adanya analisis kepuasan mahasiswa terhadap laboratorium jaringan jurusan Teknik Elektronika FT UNP diharapkan dapat dilakukan peningkatan dengan prioritas atribut yang berada di kuadran I.

\section{DAfTAR PUSTAKa}

[1] H. Winarno and Tb.Absor, "Analisis Kualitas Pelayanan Dengan Metode Service Quality (Servqual) Dan Importance Performance Analysis ( Ipa ) Pada Pt . Media Purna Engineering," J. Manajemenn Ind. dan Logistik, vol. 1, no. 2, pp. 67-79, 2017.

[2] D. M. I. Lulu Dian Anggraini, Panji Deoranto, "Analisis Persepsi Konsumen Menggunakan Metode Importance Performance Analysis Dan Customer Satifaction Index," J. Ind., vol. 4, no. 2, pp. 74-81, 2015.

[3] R. Nugraha, H. Ambar, and A. Hari, "Usulan Peningkatan Kualitas Pelayanan Jasa pada Bengkel ' $\mathrm{X}$ ' Berdasarkan Hasil Matrix (Studi Kasus di Bengkel AHASS PD . Sumber Motor Karawang)," J. Oline Inst. Teknol. Nas., vol. 1, no. 3, pp. 221-231, 2014.

[4] A. T. Sambodo, ) Harya, and B. Dirgantara, "Analisis Kepuasan Konsumen Dengan Servqual Studi Kasus: Media Sosial Bhinneka.Com," Semin. Nas. Sist. Inf. Indones., no. September, 2014.

[5] M. Mustofa, Handoyo, and D. Ernawati, "Analisis Tingkat Kualitas Pelayanan Jasa Dengan Menggunakan Metode Service Quality(Servqual) Fuzzy di PT. Pos Indonesia Sidoarjo," Tekmapro, vol. 11, no. $1,2016$.

[6] S. Ellyusman and R. F. Hutami, "Analisis Kualitas Sistem Informasi Akademik Menggunakan Metode Importance Performance Analysis ( IPA )," J. Kaji. Inf. Perpust., vol. 5, no. 1, pp. 49-62, 2017. 


\section{BiodataPenulis}

Syukhri, lahir di Padang, 9 Juni 1978. Sarjana Teknik Elektro dari Institut Teknologi Padang, lulus 2006. Tahun 2013 memperoleh gelar Magister Chief Information Officer pada Pascasarjana Fakultas Teknik Universitas Negeri Padang. System Administrator pada Unit Pelaksana Teknis Pengembangan Teknologi Informasi dan Komunikasi (UPT PTIK) Universitas Negeri Padang dari 2006 sampai 2017. Staf pengajar pada Jurusan Teknik Elektronika FT UNP sejak tahun 2017 - sekarang. 